\title{
The Impact of Apartment Development on Community Social Economic Life: Case Study on Strenkali Community-in Asemrowo, Surabaya
}

\author{
Sukriyah Kustanti Moerad, Windiani, Umi Trisyanti, and Niken Prasetyawati \\ Department of Development Studies, Institut Teknologi Sepuluh Nopember, Surabaya, Indonesia \\ e-mail: antinmoerad01@gmail.com
}

\begin{abstract}
The aims of Development for the welfare of the community, but often this development affects changes in environmental arrangements around the area which are outside the development goals. Environmental changes due to unplanned human activities have a negative impact on other social groups. Environmental impacts have the meaning of changes that can be natural or unnatural. This article aims to describe the impact of the construction of the Gunawangsa apartment, which is located around the Asemrowo River, Surabaya. This study uses a qualitative method with a case study approach. The informants in this study are people who live in the Asemrowo strenkali which is directly adjacent to the Gunawangsa Apartment Building, abaout 22 families. The results of the study found that the Gunawangsa apartment building which has been going on for 3 years has not felt the impact of significant changes in improving the family economy. The community still feels that socio-economic life is not much different from before development. The results of the research also found that the very high position of the building had hindered the catch of the television signal so that people had difficulty accessing the signal and could not comfortably enjoy television programs that were previously enjoyed well
\end{abstract}

Keywords-Development Impact, Social Economic Life, Community.

\section{INTRODUCTION}

$\mathrm{D}$ EVELOPMENT basically aims to improve the welfare of the community, but often this development affects changes in the environmental arrangements around the area which are outside of development goals. Environmental changes due to unplanned human activities have negative consequences on other social groups. Environmental Impact means a change that can be natural or unnatural. Environmental impact as an activity planned by humans can include components of the chemical, biotic, socio-economic, socio-cultural and public health environment. This impact can be a serious problem because development objectives have a more negative impact on the surrounding environment.

Surabaya has a rapid development of economic and residential activities, so it requires acceleration in the fulfillment of urban infrastructure and facilities. This plan is considered on the basis of the importance of increasing housing capacity that can be offered to the community in the form of vertical housing, especially those in the middle of the city center. Arrangement of land functions and building functions that follow the rules of spatial layout in the city of Surabaya need to be regulated with a sustainable development policy, namely by balancing economic, sociocultural and ecological aspects. So that development policies and programs will be able to increase the benefits for the

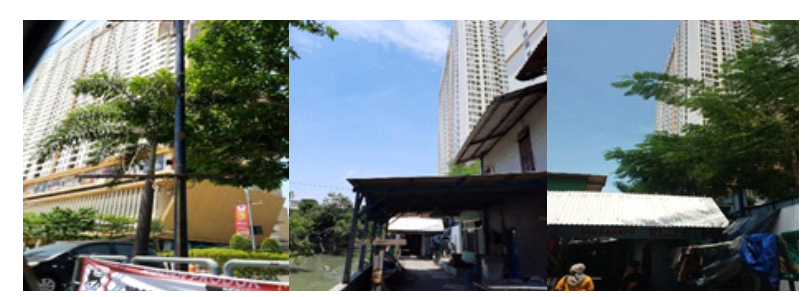

Figure 1. Research location from the side of the apartment building and next to the Asemrowo river.

surrounding community in particular, and the people of Surabaya city in general.

Furthermore, according to Arieffiani [1] in his research that, the Surabaya City Government's policy in land use and the realization of good residential development is the development of Flats and Apartments because it has effectiveness that involves the actors and the environment. This policy is contained in the Mayor of Surabaya Government Regulation Number 46 of 2013 concerning the Regional Development Work Plan (RKPD) for the City of Surabaya in 2014. Furthermore, according to Rahmawati R, et al. a house as a place to live for humans to live in a community, socializing as well as forming a small family. But the reality is that it is not easy to get the house in a proper manner. Especially for people who live in densely populated areas where the value of houses is relatively high / expensive. Likewise, they are very vulnerable to factors that cause them to lose their right to own land.

The rise of apartment development in the city of Surabaya, both on the outskirts of the city and in the middle of the city of Surabaya, has an impact on social, economic and environmental conditions. This condition is interesting to study with research questions, what are the social and economic impacts of the development of apartments that are so rampant in the city of Surabaya. This is important to know before there is an apartment construction and after an apartment development. So that the apartment development policy can be of many benefits to the people of Surabaya in general and the people around the apartment building in particular. Given that the construction of apartments in the city of Surabaya varies from being in high-economic communities to low-economic communities.

Gunawangsa Tidar Apartment is one of the apartment developments adjacent to marginalized community groups on the Asemrowo strenkali. This community group has lived in the Asemrowo strenkali since 1975 (it's been 45 years). This community occupies a house with a size of $2 \times 3$ meters, and their house is without a strong foundation, but some houses are built with 2 stories / floors and some are not. The 
December $5^{\text {th }}, 2020$, Online Conference

existence of this community is only limited to the walls of the Gunawangsa Tidar Apartment Building area. This community is legally formally located in Asemrowo Village, especially in RW05 / RT02 as seen in Figure 1.

However, the existence of their house in Strenkali, where legally constructing a building on a riverbank is something that is not allowed (an interview with one of the oldest respondents who has been in this place for 50 years and they are aware of it). This is stated in the Minister of Public Works Regulation No. 70 / PRT / 1996 concerning the determination of the equivalent lines of rivers in the working area of the general company Jasa Tirta Kali, Surabaya. The Governor of East Java KDH Level I has issued Decree No. 134 of 1997 concerning the use of riverbanks for reforestation, stockpiling, temporary excavation and vehicle parking.

The concerns or fears of residents in Asemrowo's strenkali regarding relocation / eviction are normal. This fairness is because they legally occupy the land is not allowed / prohibited. However, they have struggled to be able to build and become residents in the kelurahan where they live. Therefore, when the construction of the Gunawangsa Tidar Apartment Building was to be carried out, it triggered a high sense of concern. namely Concerns were transferred by the Surabaya City Government.

This can be seen from the results of the interview survey of the Gunawangsa Tidar Apartment Construction AMDAL activity done by S. K. Moerad in 2015, from a total of 50 respondents, there were as many as (44\%) respondents expressed concern that they would be evicted from their homes, as many $(35 \%)$ of respondents were worried about comfort problems. environment, for example, dust pollution, noise, disturbing broadcasts / damaging television electricity due to being obstructed by tall buildings, a big concern is if tall buildings suddenly collapse / collapse into their homes and, as many (21\%) of respondents expressed concern about safety. , and security (kamtibmas), social problems with the arrival of a new culture that brings different behaviors and cultures. The emergence of this sense of concern, the researcher suggests the formation of a team (group) which serves as a liaison between the community, especially in RT02, and the Gunawangsa Tidar Apartment Developer. Finally, the formation of the team was achieved in the form of an MoU that was formally acknowledged by the Kelurahan and Kecamatan with all the rules, hopes and requests that must be followed up.

This research is a continuation of research on the AMDAL activity of Gunawangsa Tidar Apartment Development, with the aim of examining the impact that arises after the construction of an apartment on social and economic conditions. Therefore, the research problem is how the socioeconomic impact that occurs with the presence of the apartment building construction. So that the benefit of the research is additional information on the Government to develop policies in the development sector for both housing and apartment buildings.

According to Homenauck [2] these socio-economic impacts can be categorized into real and special impact groups. Real impacts are impacts that arise as a result of project activities, pre-construction, construction, operation and post-operation, for example population migration, noise or air pollution. Special impact is an impact arising from the community's perception of the risks of the project.

S.K. Moerad [3] in her research on Elite Housing Development and Its Socio-Economic Impact on Local Communities (Case Study at Kejawan Putih Tambak Village) concluded that Kejawan Putih Tambak Village rt01, and 02, RW 01 have become a settlement of the village where the Pakuwon City development originated, made the domicile of Pakuwon City employees. A number (95\%) of respondents said that the atmosphere of environmental life is getting more crowded and pleasant because the economy of the people around this area is getting better and housing development has led to changes in people's livelihoods from being fish pond farmers to jobs in the self-employed and service sectors.

Employment, There are $10(16 \%)$ respondents who become permanent employees at Pakuwon City Housing, 7 (11\%) respondents as temporary daily employees (not permanent), and there are $14(23 \%)$ respondents who become entrepreneurs at Food Festival, there are 29 ( 48\%) of the respondents are private. Next is Moerad, S.K. et al. (2020) in a study on the Implementation of Urban Community Involvement in Providing Attitudes Toward Development (Case Study of Social Impact Analysis in Surabaya City Development in welcoming Conservation, concludes that there are internal and external factors in the implementation / participation of City Development.

To realize active community participation is still being faced by various obstacles both internal and external. Internal constraints faced are the high dependence of the community on the government, dependence on the incentives received, the community's limited knowledge of their participation in development and the lack of time to be able to participate in development. Development activities are due to busy work factors, while the external obstacle faced is the lack of socialization from related parties regarding development activities that will be carried out in the community. The government is even more careful, worried that social conflicts will arise if not managed properly.

Furthermore, the Sociology Expert says that socioeconomic impacts can lead to socio-economic changes, for example economic, technological, geographic or biological conditions, all of which are important in discussing the issue of social impact/social change [4]. This is also what Indarto and Rahayu said [5] in a study of the impact of housing development on the environmental, social and economic conditions of the surrounding community in Sambiroto Village, Tembalang District. They said that the existence of housing development has had an impact on social, economic and environmental impacts.

The social impact is in the form of reduced levels of community participation in social activities, increased lifestyle and decreased crime rates. The impact on the economy is in the form of increased community income, as well as the addition of housing functions to open community business fields. The impact on the environment is in the form of changes in land use, as well as a decrease in groundwater and water quality, but there is an increase in drainage and road networks.

Rieke and Legowo [6], In their research on the SocioEconomic Impact of Housing Development for the Community in Arjosari Village, Blimbing District, Malang City, the results of the study stated that housing development 


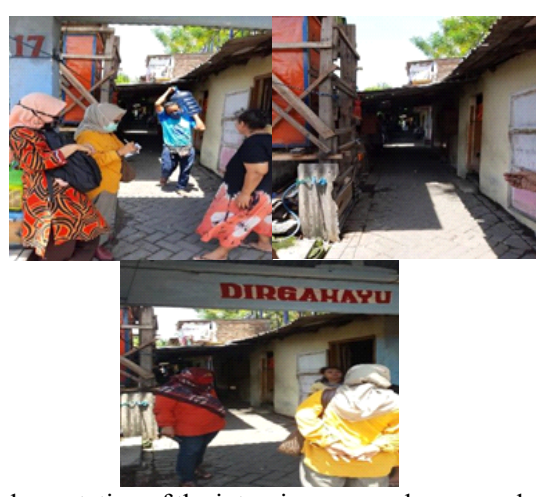

Figure 2. Implementation of the interview survey by researchers in 2020.

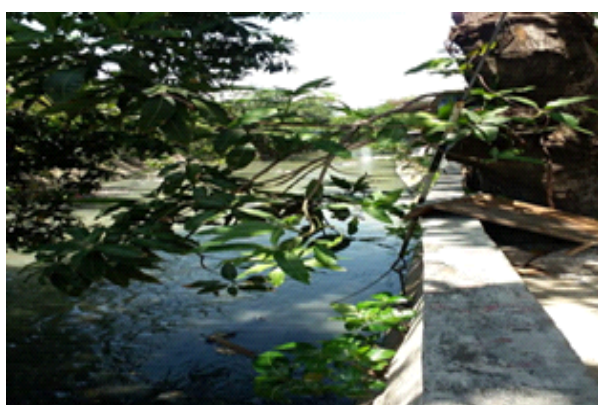

Figure 3. The location of Kali Asemrowo which coincides with the RT02 settlement, Tembok Sayuran street, the PPT Kali alley, and the Asembagus street (Pancasila alley).

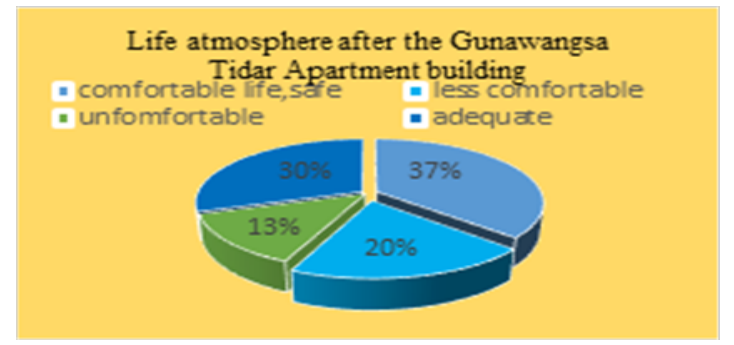

Figure 4. Current atmosphere of life according to respondents.

on Teluk Pelabuhan Ratu road, Arjosari Village, Blimbing Malang District has an influence on the socio-economic life of the local community. In addition, there is also a change in function, fenced communities, segregation, individual-group relations, stratification, new business opportunities and changes in livelihoods.

Fitriani E. et al. [7] in a study of the Impact of Housing Development on the Socio-Economic Life of Local Communities, the findings of this study are that housing development around the village area gets a positive response because it can absorb labor for the local community. Thus increasing his standard of life. On the other hand, the local community begins to lose its identity as a village community due to the imitation of the lifestyle of residents who are urban residents.

Based on the results of the research that has been done above, it shows that there are various socio-economic impacts, some are positive that can provide many benefits and some have negative impacts that actually reduce the cultural norms of the affected community. Likewise, researchers in this study will examine the socio-economic impact after the establishment of the Gunawangsa Tidar Apartment Building. The social study that is seen is that social life includes a sense of community solidarity / attention, togetherness in society, social life in the community, and the economy is related to

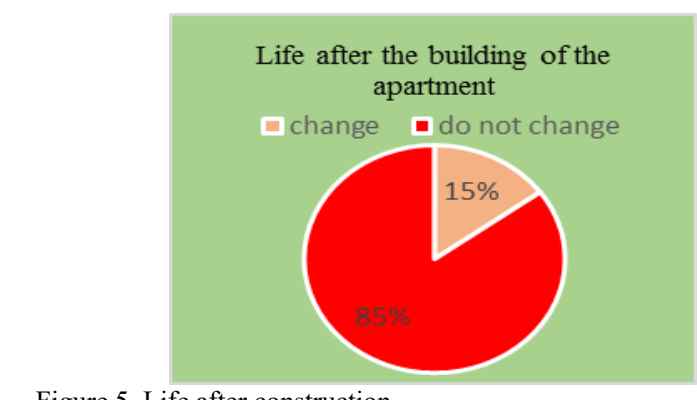

Figure 5. Life after construction.

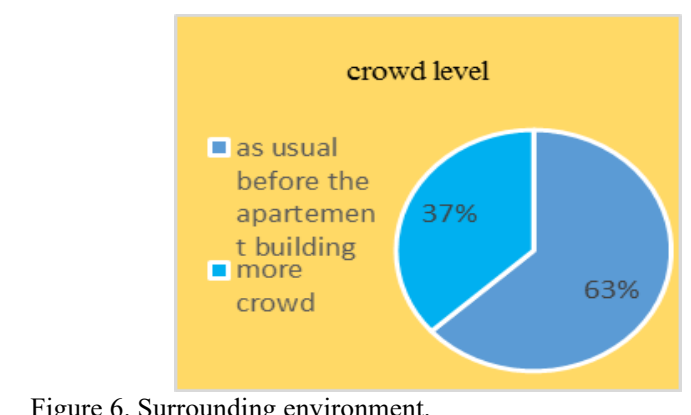

the type of work, business opportunities, job opportunities.

\section{METHOD}

In this study, researchers used a qualitative descriptive approach. Research variables include: social impacts and economic impacts. Qualitative descriptive is research that leads to disclosing a problem or situation as it is and revealing the facts. Descriptive research needs to create scientific concepts, as well as to function in interpreting a specification regarding the physical and social symptoms in question, as well as providing a description of the state of the object under study [8].

The research was conducted using survey, observation and interview methods as seen in Figure 2. The interview guide is use an instrument, research according to Arikunto [9], is a tool used by researchers in disclosing data so that their work is easier and the results are better in the sense of being accurate, complete, systematic, so that it is easy to process.

The research instrument is a questionnaire / list of questions which is a closed question where the respondent chooses one of the answers according to his character. Social impacts include attitudes / opinions, environmental comfort, social phenomena in social life. Meanwhile, the economic impact includes job opportunities, jobs and business opportunities. In making the questionnaire, the researcher used a Likert scale. Sugiyono [10] states that the Likert Scale is used to measure the attitudes, opinions and perceptions of a person or group of people about social phenomena.

The research location is in Asemrowo Village, especially in RW 05 / RT 02. The research population is residents in RT02, especially those in Strenkali Asemrowo, in the RT02 area it is divided into 2 parts, namely on Jalan Tembok sayur alley PPT as seen in Figure 3, which are inhabited by approximately 27 heads Families, and on Jalan Asem Bagus, Pancasila alley with a population of approximately 45 families. In total, the population in RT 02 is approximately 75 households. The sampling technique was random 
The $2^{\text {nd }}$ International Conference on Global Development - ICODEV

December $5^{\text {th }}, 2020$, Online Conference

sampling. Due to several reasons for the obstacles to interviewing, the random sampling of respondents was limited to only 30 respondents (the head of the family), with the help of several informants in the study area. The primary data collection technique was carried out by means of a questionnaire and interviewing informants and respondents. Meanwhile, data processing by frequency tabulation used is descriptive quantitative. Data analysis was carried out descriptively.

\section{RESULT AND DISCUSSION}

Asemrowo sub-district is one of the sub-districts in the city of Surabaya, located in the West Surabaya area with an altitude of approximately 2.5 meters above sea level. Based on data from the Central Statistics Agency (BPS) for the city of Surabaya 2019, Asemrowo District has an area of 13.06 $\mathrm{Km} 2$ and is divided into three sub-districts namely, Tambak Sarioso Village, Asemrowo Village and Genting Kalianak Village. The study was in Asemrowo Village, which has a population of 33,642 in 2019, consisting of 17,130 men and 16,512 women with a sex ratio of 103.74 . The mobility of the population in Asemrowo Village is as follows, the birth rate is 61 people and 11 deaths are, the migration rate is 29 people, the arrival rate is 38 new arrivals. The Gunawangsa Tidar Apartment is one of the Gunawangsa Group which was built since 2014 and is currently completed (95\%) of the building in 2018, and it was inaugurated and operated in 2018.

The results of the primary data research obtained during the survey, observation and interview showed the following characteristics of the respondents: a number $(60 \%)$ of the respondents were male, and a number $(40 \%)$ of the respondents were female. With age $(<20$ years $)$ there are $(10 \%)$ respondents, age (21-30 years) there are $(27 \%)$ respondents, age (36-51 years) there are (40\%) respondents and age ((51-66 years) as many as (23\%) of respondents. The education level classification of respondents is as follows, $(20 \%)$ of respondents with junior high school education, there are $(63 \%)$ respondents with high school education, and there are $(17 \%)$ respondents with undergraduate education. Thus the characteristics of the respondents are random sampling already represented by gender, age structure and level of education. Furthermore, analysis of social life with the presence of apartment buildings as follows.

\section{A. Impact of Social Life and Social Relations}

According to respondents, the results of the questionnaire answers $(70 \%)$ of respondents stated that they were okay even though there was construction of the Gunawangsa Apartment, and $(17 \%)$ respondents said that sometimes it was not good because of noise, noise from the apartment building, and $(13 \%)$ respondents gave no answer. This statement is actually a bit contradicting the time of the survey for the AMDAL of this apartment development plan which is done by Moerad in 2014 where when the people in this study area expressed more hesitation (50\%) of a total of 60 respondents regarding the development plan. This is because the community feels anxious/fearful about tall buildings that are very close to their homes. There are also (37\%) respondents stated that life is currently comfortable, safe, and are used to being side by side with the apartment area, and (20\%) respondents stated that they are not comfortable because they are still worried about a tall building right next to their house, and (13\%) respondent stated that it was not as comfortable as it used to be before this tall building was due to the fact that many aspects of the kinship between them were lost, and (30\%) of respondents stated that life is mediocre as seen in Figure 4.

Furthermore, the respondent's statement about life after the existence of the apartment building ,is there any change? There are a number $(85 \%)$ of respondents who stated that there is no significant change so that it remains as before, and only (15\%) (as seen in Figure 5) of respondents stated that there has been a change even though it is not visible. In the opinion of the researchers, there are several possibilities for this to happen, because the operational construction of an apartment building is still relatively short, secondly because there are no people in the research area who have become permanent employees who can be used by residents who can improve their economy, there are environmental factors where the research location is relatively close to the center the city of Surabaya, so that the development is not too concerned about the social life of the community. This is different from the impact of development in rural areas such as the results of research by Fitriani E. et al. [7] entitled The Impact of Housing Development on the Socio-Economic Life of Local Communities, (Case Study of Community SocioEconomic Life in Ligar Mekar Village, Cibeunying Village, Bandung Regency). The findings from the results of this study are that housing development around the village area gets a positive response because it can absorb labor for the local community.

Likewise, the level of crowd and community togetherness with the presence of development, as seen in Figure 6 only $37 \%$ of respondents said it was getting more crowded because in the Gunawangsa Apartment area there were shopping centers, so that according to the respondent's information, many of the local people used it.

When the social survey of the AMDAL for the construction of the Gunawangsa Tidar Apartment was made an MoU between the affected community and the management, and what respondent information was disclosed at the $\mathrm{MoU}$, the management had carried out, including if there was a crack in the respondent's house, the community was sick, as well as the incentives provided every year, all of these things have been carried out by the management. Even the information that the researchers got from the informants of this study, the management has fixed the problem of the signal flow to the television, by building a tower but it still does not produce a good, clean and clear signal. This is until this research was carried out the condition of the television signal was still bad. During the construction period, the wall in the area of the house in the study area collapsed, so the management immediately repaired it. Details such as the data in the table below.

Next, if you look at the results regarding the current social conditions after the existence of an apartment building, it is as in the Table 1.

\section{B. Economic Impact}

Respondents' statements regarding job opportunities during construction to date for people in the study area as seen in Figure $7(10 \%)$ of respondents stated that there are job 
December $5^{\text {th }}, 2020$, Online Conference

Table 1.

Current Social Conditions of Asemrowo Strenkali Community

\begin{tabular}{ll}
\hline \hline $\begin{array}{l}\text { Social relations between } \\
\text { residents and residents }\end{array}$ & $25 \%$ said good, harmonious \\
of the apartment & $75 \%$ said it was so \\
& $40 \%$ said there was \\
Cooperation activities & $25 \%$ said it sometimes \\
& $35 \%$ said none \\
& $65 \%$ said there was \\
Social assistance & $30 \%$ said they did not know \\
& $5 \%$ said none \\
& $70 \%$ said there was \\
Home improvement & $25 \%$ said they do not know \\
& $5 \%$ said none \\
& $75 \%$ said there was \\
& $15 \%$ said they did not know \\
Health maintenance & $10 \%$ they did not answered \\
Incentives Giving & $80 \%$ said there was \\
& $20 \%$ said they did not know \\
\hline \hline
\end{tabular}

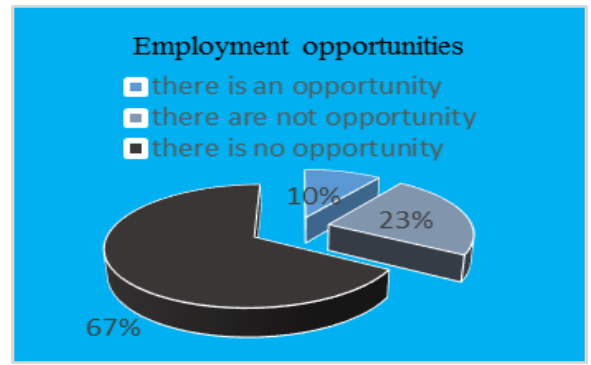

Figure 7. Job opportunities respondents.

opportunities and currently not all residents in RT02 become permanent workers in apartments, and there are (67\%) respondents stated when There are no job opportunities for the people here, and $(23 \%)$ of the respondents stated that they did not know. This condition is different from the results of research [3], Research on Elite Housing Development and Its Socio-Economic Impact on Local Communities (Case Study of Kejawan Putih Tambak Village), where the aspect of employment, there are $10(16 \%)$ respondents become permanent employees at In Pakuwon City Housing, there are $7(11 \%)$ respondents who are casual daily employees (not permanent), and there are $14(23 \%)$ respondents who are selfemployed at Food Festival.

These opportunities can be enjoyed by the community around the housing estate and have become permanent employees, there are security, gardeners, electronic repair, electricity and cleaning services. However, the results of the research here that there are differences in these impacts could be possible because the evaluation for the construction of this apartment is still in a new period (4 years of operation). Meanwhile, at Kejawan Putih Tambak, it has been approximately 25 years.

Likewise for business opportunities, as seen in Figure 8 the statement of respondents in this research area only $(7 \%)$ of respondents stated that there is a business opportunity, they can still sell near apartments that can provide rice stalls for apartment employees, and (73\%) respondents said there was no business opportunity, and (20\%) respondents said they did not know. This is when we look at the results of research [11] in the research "Mapping the Potential and Economic Impacts of Communities in the Bukit Tumpang Pitu Mining Area,
Banyuwangi (Case Study of the Impact of Mining on Communities in Sumber Agung Village, Banyuwangi), there was a shift in their original livelihoods / jobs into a community of rice and field farmers, to become gold miners, an increase in income, and an economic multiplier effect on other activities.

\section{CONCLUSION}

\section{A. Conclusion}

The presence of development essentially aims to improve the quality of socio-economic life of the community. People are always faced with several options. Whether it's the option to accept or reject development. The presence of apartments, especially those in the research area and have been operating for about 4 years, based on the results of the above research, it can be concluded:

1. It has not shown a positive impact in terms of improving the economy of the people in the research area.

2. It cannot feel the social impact of social diversity in society.

3. However, on the other hand, there is already an impact in accordance with the agreement made when the construction will be carried out. The developer has implemented it according to the agreement even though it has not made the people in the research area fully satisfied.

4. As a matter of concern, the people in the research area do not bring their concerns into polemics or problems as people who live in the Asemrowo strategic area.

5. The conclusion of this study is different from the results of research that has been widely implemented, there are different causes, namely location, community characteristics. So that the development impact that occurs cannot be equated, especially the case study in this research.

\section{B. Suggestion}

1. The developer is expected to provide job opportunities as well as business opportunities that exist and can be utilized by the community in the research area.

2. This research will still be continued if it has been up to 15 years of development operations in this research area.

3. The data obtained in this study can be a little additional information for the government

\section{REFERENCES}

[1] D. Affieffiani., "Kebijakan pembangunan perumahan pemerintah kota surabaya dan konsistensi terhadap pemanfaatan lahan," Jurnal Sosial Humaniora. vol. 7 no.1, pp. 45-60, 2014 doi: 10.12962/j24433527.v7i1.595

[2] S. P. Hadi, Aspek Sosial Amdal, Yogyakarta: Gadjah Mada University Press.

[3] S.K. Moerad, T. S. Rini, and L. Rosdiana, "Pembangunan Perumahan Elite dan Dampak Sosial Ekonominya Terhadap Masyarakat Setempat (Studi Kasus Perkampungan Kejawan Putih Tambak)," in Seminar Teknologi dan Perubahan Sosial 3 2018, ITS Surabaya, Sep. 2018. [Online]. Available: IPTEK, Journal of Procceding Series doi: 10.12962/j23546026.y2018i5.4440 
The $2^{\text {nd }}$ International Conference on Global Development - ICODEV

December $5^{\text {th }}, 2020$, Online Conference

[4] S. Soekanto, Sosiologi Suatu Pengantar. Jakarta: PT. Rajagrafindo Persada, 2006

[5] K. D. Indarto and S. Rahayu, "Dampak pembangunan perumahan terhadap kondisi lingkungan, sosial dan ekonomi masyarakat sekitar di kelurahan sambiroto, kecamatan tembalang," Jurnal Teknik PWK, vol. 4 no. 3, pp. 428-439, 2015 url:http://ejournalsl.undip.ac.id/index.php/pwk

[6] R. Rieke and M. Legowo, "Dampak sosial ekonomi pembangunan perumahan bagi masyarakat di kelurahan arjosari kecamatan blimbing kota malang," Journal Paradigma, vol. 4 no. 3, pp..1-10, 2016 url: https://jurnalmahasiswa.unesa.ac.id/index.php/paradigma/article/view $/ 16502 / 14994$

[7] E. Fitriani, E. Malihah, and M. N. Alia, "Dampak pembangunan perumahan terhadap kehidupan sosial ekonomi masyarakat setempat (studi kasus kehidupan sosial ekonomi masyarakat di desa ligar mekar, kelurahan cibeunying, kabupaten bandung)," Jurnal Antologi, vol. 16 no. $1, \quad$ pp. $1-15, \quad 2016 \quad$ url: http://sosiologi.upi.edu/unduhjournal.php?file=6_antologi_vol6_Erin $\%$ 20Fitriani.pdf

[8] H. M. P. Tika, Metode Peneltian Geografi, Jakarta: Bumi Aksara, 2005

[9] A. Arikunto and S. Suharsimi, Prosedur Penelitian: Suatu Pendekatan Praktek, Jakarta: Rineka Cipta, 2010

[10] S. Sugiyono, Metode Penelitian Kuantitatif Kualitatif dan $R \& D$ Bandung: Alfabeta, 2014

[11] S.K. Moerad, W. Windiani. E. Susilowati, "Pemetaan potensi dan dampak ekonomi masyarakat di kawasan pertambangan bukit tumpang pitu banyuwangi," Jurnal Sosial Humaniora, vol 9 no. 2, pp.114-138, 2016, doi: /10.12962/j24433527.v912.1621 